\title{
Effects of 8-mer acidic peptide concentration on the morphology and photoluminescence of synthesized $\mathrm{ZnO}$ nanomaterials
}

\author{
Chung Hee Moon ${ }^{1} \cdot$ Marzieh Tousi $^{2} \cdot$ Joseph Cheeney $^{1} \cdot$ Tam-Triet Ngo-Duc $^{1}$ \\ Zheng $\mathrm{Zuo}^{3} \cdot$ Jianlin $\mathrm{Liu}^{3} \cdot$ Elaine D. Haberer ${ }^{1,3}$
}

Received: 28 July 2015/Accepted: 31 August 2015/Published online: 5 September 2015

(C) Springer-Verlag Berlin Heidelberg 2015

\begin{abstract}
An 8-mer ZnO-binding peptide, VPGAAEHT, was identified using a M13 pVIII phage display library and employed as an additive during aqueous-based $\mathrm{ZnO}$ synthesis at $65{ }^{\circ} \mathrm{C}$. Unlike most other well-studied $\mathrm{ZnO}$ binding sequences which are strongly basic $(\mathrm{pI}>\mathrm{pH} 7)$, the 8-mer peptide was overall acidic $(\mathrm{pI}<\mathrm{pH} 7)$ in character, including only a single basic residue. The selected peptide strongly influenced $\mathrm{ZnO}$ nanostructure formation. Morphology and optical emission properties were found to be dependent on the concentration of peptide additive. Using lower peptide concentrations $(<0.1 \mathrm{mM})$, single crystal hexagonal rods and platelets were produced, and using higher peptide concentrations $(\geq 0.1 \mathrm{mM})$, polycrystalline layered platelets, yarn-like structures, and microspheres were assembled. Photoluminescence analysis revealed a characteristic $\mathrm{ZnO}$ band-edge peak, as well as sub-bandgap emission peaks. Defect-related green emission, typically associated with surface-related oxygen and zinc vacancies, was significantly reduced by the peptide additive, while blue emission, attributable to oxygen and zinc interstitials, emerged with increased peptide concentrations. Peptide-directed synthesis of $\mathrm{ZnO}$ materials may
\end{abstract}

Electronic supplementary material The online version of this article (doi:10.1007/s00339-015-9475-7) contains supplementary material, which is available to authorized users.

Elaine D. Haberer

haberer@ucr.edu

1 Materials Science and Engineering Program, University of California, Riverside, CA 92521, USA

2 Department of Chemical and Environmental Engineering, University of California, Riverside, CA 92521, USA

3 Department of Electrical and Computer Engineering, University of California, Riverside, CA 92521, USA be useful for gas sensing and photocatalytic applications in which properly engineered morphology and defect levels have demonstrated enhanced performance.

\section{Introduction}

Zinc oxide $(\mathrm{ZnO})$ is a wide bandgap semiconductor (3.37 eV), with high exciton binding energy $(60 \mathrm{meV})$. Its unique electrical and optical properties have led to its widespread use in optoelectronic, piezoelectric, gas sensing, and photocatalytic devices, among others [1]. Morphology, particle size, crystallinity, and point defects must be modified to provide specialized physical properties required for each application. While single crystal, defectfree materials are typically essential for optoelectronic and piezoelectric applications, polycrystalline materials are largely acceptable for gas sensing and photocatalytic applications. Moreover, gas sensor performance can be enhanced by the accumulation of some defects which act as donors or preferential binding sites [2, 3]. In addition, the presence of sub-bandgap defect levels can improve electron-hole pair separation through trap-mediated charge transfer, which is desirable for photocatalytic applications [4-6]. In order to effectively tune $\mathrm{ZnO}$ properties, a range of synthesis methods including chemical vapor deposition, sol-gel processing, and aqueous-based chemistry has been reported [1].

More recently, synthesis assisted by biological molecules such as collagen [7], proteins [8], and peptides [9-13] has been introduced as a promising alternative $\mathrm{ZnO}$ growth strategy. Biomolecules allow formation of crystalline $\mathrm{ZnO}$ under environmentally benign conditions, which include mild temperature, atmospheric pressure, and aqueous 
solution. Among biomolecules, peptides have been studied extensively due to the specificity and chemical diversity made possible by their amino acid building blocks, and the ease of discovery afforded by combinatorial display techniques. Several peptides with high affinity for $\mathrm{ZnO}$ have been identified using phage or bacteria surface display [911, 14-16]. Like many naturally occurring zinc-binding proteins, the majority of the reported peptides have been net basic peptides ( $\mathrm{pI}>\mathrm{pH} 7)$, rich in arginine (R), histidine $(\mathrm{H})$, or lysine $(\mathrm{K})$ residues. In addition to binding capability, a handful of the identified peptides have demonstrated an ability to influence crystal growth by serving as either capping agents $[11,17]$ or nucleation sites [12] to form characteristic nanoparticles [10], nanorods [11, 12], nanoplatelets [11, 17], and nanoflowers [9]. Despite strong interest in material formation mechanisms, crystallinity, and morphology, optical and electrical behavior of the resulting bio-directed materials has been largely neglected.

Here, an 8-mer M13 bacteriophage pVIII library was used to identify peptides with an affinity for $\mathrm{ZnO}$. Because viral protein packing restricts the size and electrostatic charge of pVIII peptide fusions, net basic fusions tend to inhibit efficient capsid assembly and have low frequency within this library, allowing exclusive discovery and study of neutral to acidic peptides. In this work, an acidic peptide sequence (VPGAAEHT) with an affinity for $\mathrm{ZnO}$ was found and used to as an additive during $\mathrm{ZnO}$ synthesis. The resulting nanoscale $\mathrm{ZnO}$ materials were characterized, including photoluminescence measurements as a function of peptide concentration. During synthesis, this acidic, hydrophobic peptide modified $\mathrm{ZnO}$ crystallinity, morphology, and defect level emission, suggesting potential for use in photocatalytic and gas sensing material formation.

\section{Experimental}

Peptides with affinity for $\mathrm{ZnO}$ were identified using combinatorial phage display technology [18]. A M13 phage display library with a random 8-mer peptide fused to the $\mathrm{N}$-terminus of the pVIII coat protein was constructed with a previously reported method [19]. The library, with a diversity of $3.65 \times 10^{7}$, was added to $1 \mathrm{mg} / \mathrm{mL} \mathrm{ZnO}$ powder (Sigma-Aldrich) dispersed in Tris-buffered saline with $0.1 \%$ Tween-20 (TBST, $50 \mathrm{mM}$ Tris-Cl, $150 \mathrm{mM}$ $\mathrm{NaCl}, \mathrm{pH} 7.5$ ) and incubated at room temperature for $1 \mathrm{~h}$ to allow phages to bind. Unbound and weakly bound phages were removed from the $\mathrm{ZnO}$ powder by repeated washing in $0.1 \%$ TBST. Bound phages were physically eluted from the powder surface by sonication in $0.7 \%$ TBST for $1 \mathrm{~min}$ [20]. The eluate was amplified and used for the next selection round. After five screening passes, DNA from the eluted phages was sequenced (Applied Biosystems $3730 \times 1$ DNA Sequencer) to identify binding peptides. The most recurrent phage and associated 8-mer $\mathrm{ZnO}$ binding peptide were chosen for further study.

Phage binding strength was determined by incubating $1 \times 10^{11}$ pfu of phages with a thin film of $\mathrm{ZnO}$ grown by molecular beam epitaxy on a (100) $\mathrm{Si}$ substrate $(\mathrm{ZnO} / \mathrm{Si})$ in $0.1 \%$ TBST for $1 \mathrm{~h}$. Following multiple washes with $0.5 \%$ TBST, the bound phages were physically eluted by sonication of the $\mathrm{ZnO} / \mathrm{Si}$ substrate in $0.7 \%$ TBST for $1 \mathrm{~min}$. The phage concentration of the eluate or binding strength was determined by titering. The binding strengths of the recurrent $\mathrm{ZnO}$-binding and wild-type phages were each measured four times. Average values were reported. The same procedure was also completed for both phages with a (100) Si substrate. To isolate the binding strength associated with $\mathrm{ZnO}$, the average binding strength for (100) $\mathrm{Si}$ was subtracted from that of $\mathrm{ZnO} / \mathrm{Si}$.

The ZnO-binding peptide was synthesized with a GGGSC linker (Biomatik) and suspended in TBS. Equimolar zinc nitrate hydrate $\left(\mathrm{Zn}\left(\mathrm{NO}_{3}\right)_{2} \cdot \mathrm{H}_{2} \mathrm{O}\right.$, SigmaAldrich) and hexamethylenetetramine (HMTA, SigmaAldrich) precursors were mixed to $50 \mathrm{mM}$ in $300 \mu \mathrm{L}$ of deionized water. ZnO-binding peptides from 0 to $0.6 \mathrm{mM}$ were added to the precursors and incubated in $65^{\circ} \mathrm{C}$ oven for $24 \mathrm{~h}$. Precipitates were washed twice with deionized water and collected through centrifugation. Transmission electron microscopy (TEM) samples were prepared by drop casting washed precipitates onto carbon-coated copper grids followed by two water washes and gentle air dry. Elemental composition and crystal structure were determined by energy-dispersive X-ray spectroscopy (EDS) and electron diffraction analysis using TEM (FEI CM300). Scanning electron microscopy (SEM) samples were prepared by drop casting and drying the precipitates on clean $\mathrm{Si}$ wafers. The morphology of the synthesized materials was observed with SEM (Phillips XL30 FEG), and the aspect ratio (length/diameter) of the structures was measured. Photoluminescence (PL, Horiba Jobin-Yvon Spex Fluorolog) measurements of drop cast $\mathrm{ZnO}$ materials were made at room temperature using $320 \mathrm{~nm}$ excitation and spectra were normalized to either the band-edge or near band-edge emission peak. Fourier transform infrared spectroscopy (FTIR, Nicolet 6700 Thermo Scientific) analysis from 1300 to $1800 \mathrm{~cm}^{-1}$ was performed on vacuum-dried precipitates in powdered form.

\section{Results and discussion}

Combinatorial phage display screening using the M13 pVIII library identified several peptide sequences (Supplementary material, Table S1) with affinity for $\mathrm{ZnO}$, all of 
which were acidic in nature ( $\mathrm{pI}<\mathrm{pH} 7)$. One peptide, VPGAAEHT, was displayed on 7 out of the 23 phages sequenced and stood out as the strongest $\mathrm{ZnO}$ binder. This peptide sequence, depicted in Fig. 1a, was selected for further study and will hereafter be referred to as the $\mathrm{ZnO}$ binding peptide [21]. It included the charged amino acid residues histidine $(\mathrm{H})$ and glutamate $(\mathrm{E})$, and was rich in hydrophobic residues. The affinity of the $\mathrm{ZnO}$-binding phage was evaluated via binding study. Figure $1 \mathrm{~b}$ shows the average binding strength of the $\mathrm{ZnO}$-binding and wildtype phages for $\mathrm{ZnO}$, respectively. The $\mathrm{ZnO}$-binding phage was found to have an affinity for $\mathrm{ZnO}$ which was 228 times larger than that of the wild-type phage. Moreover, as depicted in Fig. 1b (inset), immediate agglomeration was observed when the $\mathrm{ZnO}$-binding phages were added to a nanoparticle suspension. It is notable that the affinity of the identified $\mathrm{ZnO}$-binding phage was robust, demonstrating binding capability for three different forms of $\mathrm{ZnO}$ : powder, nanoparticles, and thin film.

To study the effects on $\mathrm{ZnO}$ formation, the $\mathrm{ZnO}$-binding peptide with functional linker (-GGGSC) [9] was added during $\mathrm{ZnO}$ synthesis. $\mathrm{Zn}\left(\mathrm{NO}_{3}\right)_{2}$ and HMTA precursor concentrations were held constant at $50 \mathrm{mM}$, while the peptide concentration was varied from 0 to $0.6 \mathrm{mM}$. Figure 2 shows electron diffraction patterns and TEM images (inset) of the resulting nanostructured material for each synthesis condition. Although diverse particle

(a)
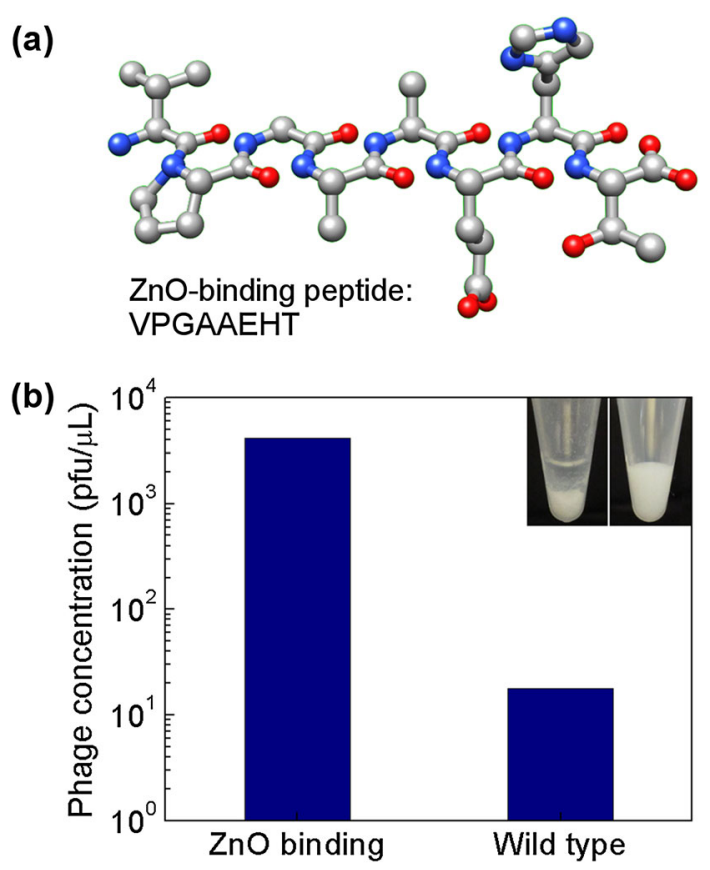

Fig. 1 a Ball-and-stick model of identified ZnO-binding peptide sequence, VPGAAEHT. b The binding strength of the ZnO-binding and the wild-type phages for $\mathrm{ZnO}$. Inset shows optical images of $\mathrm{ZnO}$ nanoparticle dispersion (left) with and (right) without the addition of the $\mathrm{ZnO}$-binding phage morphologies were observed, a diffraction pattern consistent with wurtzite $\mathrm{ZnO}$ was obtained for all samples [22]. A transition from single- to poly-crystalline material was apparent for peptide concentrations $\geq 0.1 \mathrm{mM}$. Elemental analysis of all samples using EDS revealed $\mathrm{Zn}$ and $\mathrm{O}$ peaks. Representative EDS spectra are shown in Fig. 3.

SEM images of the $\mathrm{ZnO}$ materials are shown in Fig. 4. Material synthesized without peptides had a hexagonal needle-like structure $[11,23]$. With the addition of peptides, this morphology changed to flat-ended rods and, at high peptide concentrations, to microspheres. At or below $0.05 \mathrm{mM}$, the observed $\mathrm{ZnO}$ structures retained hexagonal facets but decreased in aspect ratio from 11 to 1.6 with increasing peptide concentration, as shown in Fig. 5. A similar morphological change has also been observed in synthesis aided by a handful of previously reported, basic peptides with $\mathrm{ZnO}$ affinity [11, 24]. These peptides displayed preferential binding on (0001) planes which inhibited or slowed $c$-axis growth, causing for the formation of plates. Interestingly, for one of these peptides, the use of the -GGGC linker increased binding selectivity for the (0001) places and further reduced aspect ratio [17]. Although histidine and cysteine are known to complex with $\mathrm{Zn}^{2+}$, particularly in zinc finger proteins, histidine or cysteine monomers do not induce a needle to rod transition $[13,23]$. Moreover, only a handful of histidine-containing dipeptides, composed of only two amino acids, have been shown to cause such a change [23]. As such, the single histidine residue within the VPGAAEHT sequence or the cysteine residue within the linker was not likely alone responsible for the morphological change observed here, but rather the combination of amino acids within the discovered $\mathrm{ZnO}$-binding peptide influenced crystal growth collectively. Above $0.05 \mathrm{mM}$, layered $(0.1 \mathrm{mM}$, $0.16 \mathrm{mM})$, yarn-like $(0.31 \mathrm{mM})$, and microsphere $(0.6 \mathrm{mM})$ morphologies composed of smaller, hierarchically arranged particles were found. This morphological observation corroborated the increased polycrystallinity in the electron diffraction data. The assembly of smaller $\mathrm{ZnO}$ nanoparticles into larger structures such as flowers [9] and olives [25] has also been observed under different bioassisted synthesis conditions. In addition to the capping effect mentioned previously, the rise of peptide-peptide interactions at higher peptide concentrations likely promoted this kind of long-range organization [26, 27].

It is notable that the morphological changes seen with the 8-mer acidic peptide were more significant than those recorded for 12-mer basic peptides [11, 17]. Under similar peptide concentrations and synthesis conditions, highly investigated basic peptides supported an aspect ratio change from needle to plate, whereas the 8-mer acidic peptide moved beyond a simple difference in height-width relationship forming more complex structures. 

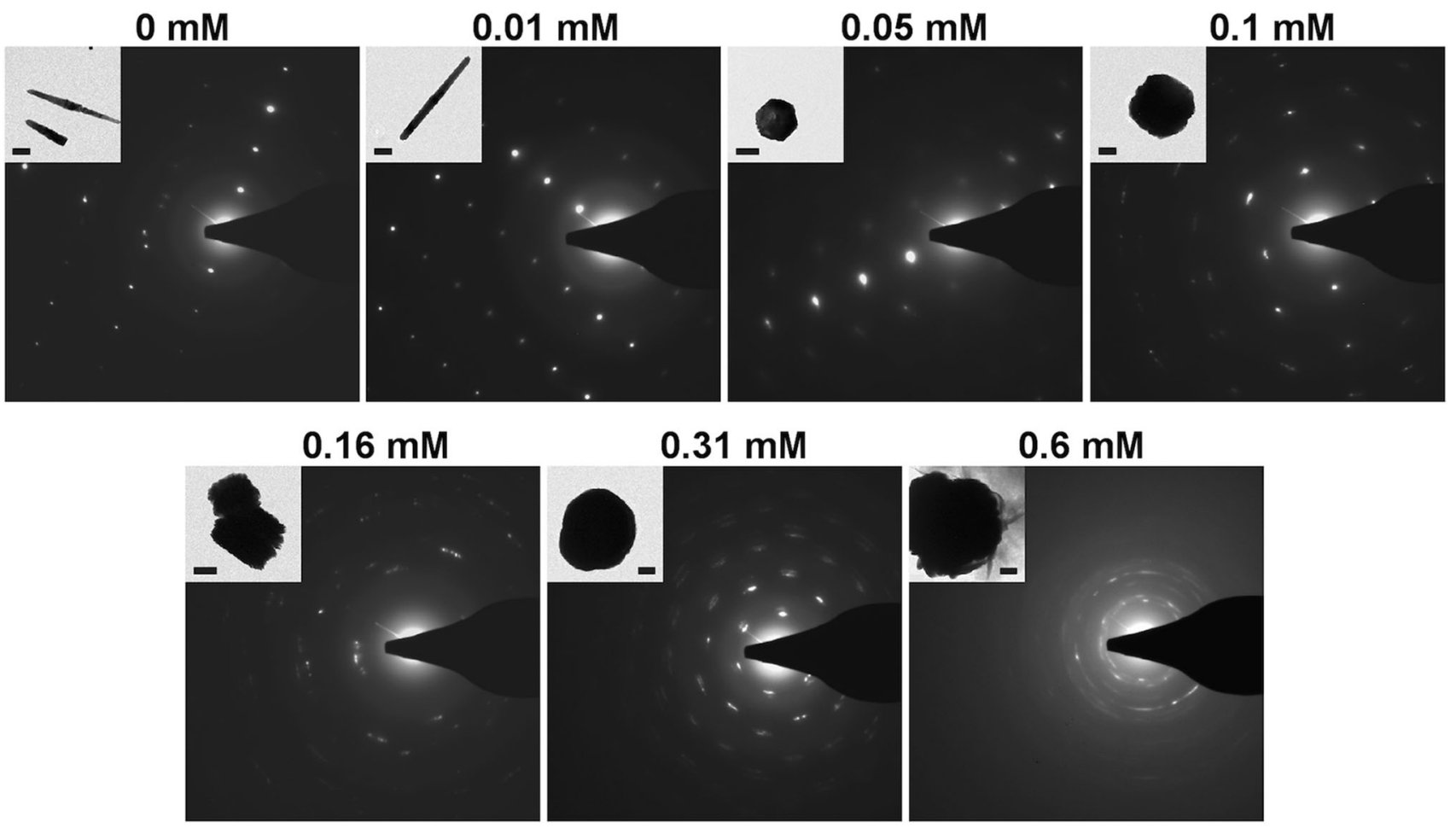

Fig. 2 Transmission electron microscopy (TEM) images (inset, scale bar $0.5 \mu \mathrm{m}$ ) and corresponding electron diffraction patterns of ZnO nanostructures synthesized with varied peptide concentrations

(a)

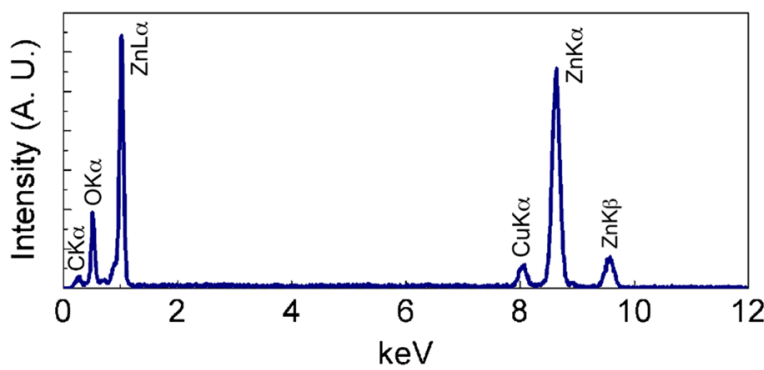

(b)

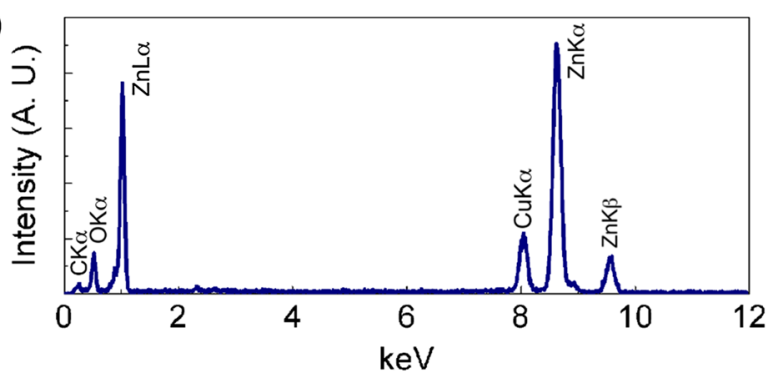

Fig. 3 Representative energy-dispersive X-ray spectra (EDS) of peptide-assisted structures synthesized with a no peptide and b $0.6 \mathrm{mM} \mathrm{ZnO}$-binding peptide on carbon-coated copper TEM grid

To assess peptide adsorption or incorporation in the peptide-assisted $\mathrm{ZnO}$ nanostructures, FTIR analysis was performed. Representative spectra in the wavenumber region of interest appear in Fig. 6. Peptide characteristic amide I and amide II absorption peaks at 1500-1600 and
$1600-1700 \mathrm{~cm}^{-1}$, respectively, were observed in the peptide alone and $\mathrm{ZnO}$ structures formed in presence of $0.1 \mathrm{mM}$ ZnO-binding peptide. Notably, the amide II shifted from $\sim 1670 \mathrm{~cm}^{-1}$ in the peptide only sample to $1645 \mathrm{~cm}^{-1}$ in the peptide-assisted $\mathrm{ZnO}$ structure, suggesting peptide adsorption onto the $\mathrm{ZnO}$ materials $[17,28]$. $\mathrm{ZnO}$ synthesized without peptide did not show amide absorption peaks; however, broad features were present in the $1300-1450 \mathrm{~cm}^{-1}$ range which were also seen in the $0.1 \mathrm{mM}$ peptide-assisted $\mathrm{ZnO}$ materials. Although exact attribution of these peaks needs to be elucidated, absorption of $\mathrm{CO}_{2}{ }^{-}, \mathrm{CO}_{3}{ }^{2-}$, and $\mathrm{CH}_{3}$, and $\mathrm{NO}_{3}$ which could be related to $\mathrm{ZnO}$ intermediate states has been reported within this range $[13,28]$.

Optical behavior of $\mathrm{ZnO}$ materials synthesized with peptide additives was investigated using photoluminescence measurements. Figure 7 shows the normalized emission spectra of the $\mathrm{ZnO}$ structures synthesized with different peptide concentrations. The spectra of material synthesized without peptides and with peptide concentrations of $0.1 \mathrm{mM}$ or less showed a distinct peak near $380 \mathrm{~nm}$, which was consistent with $\mathrm{ZnO}$ band-edge emission $(3.2-3.4 \mathrm{eV}) . \mathrm{ZnO}$ materials prepared without peptides also displayed strong green emission between 520 and $545 \mathrm{~nm}$ associated with electron-hole recombination at deep level defects such as surface-related oxygen and zinc vacancies [29]. Notably, this green emission peak was 

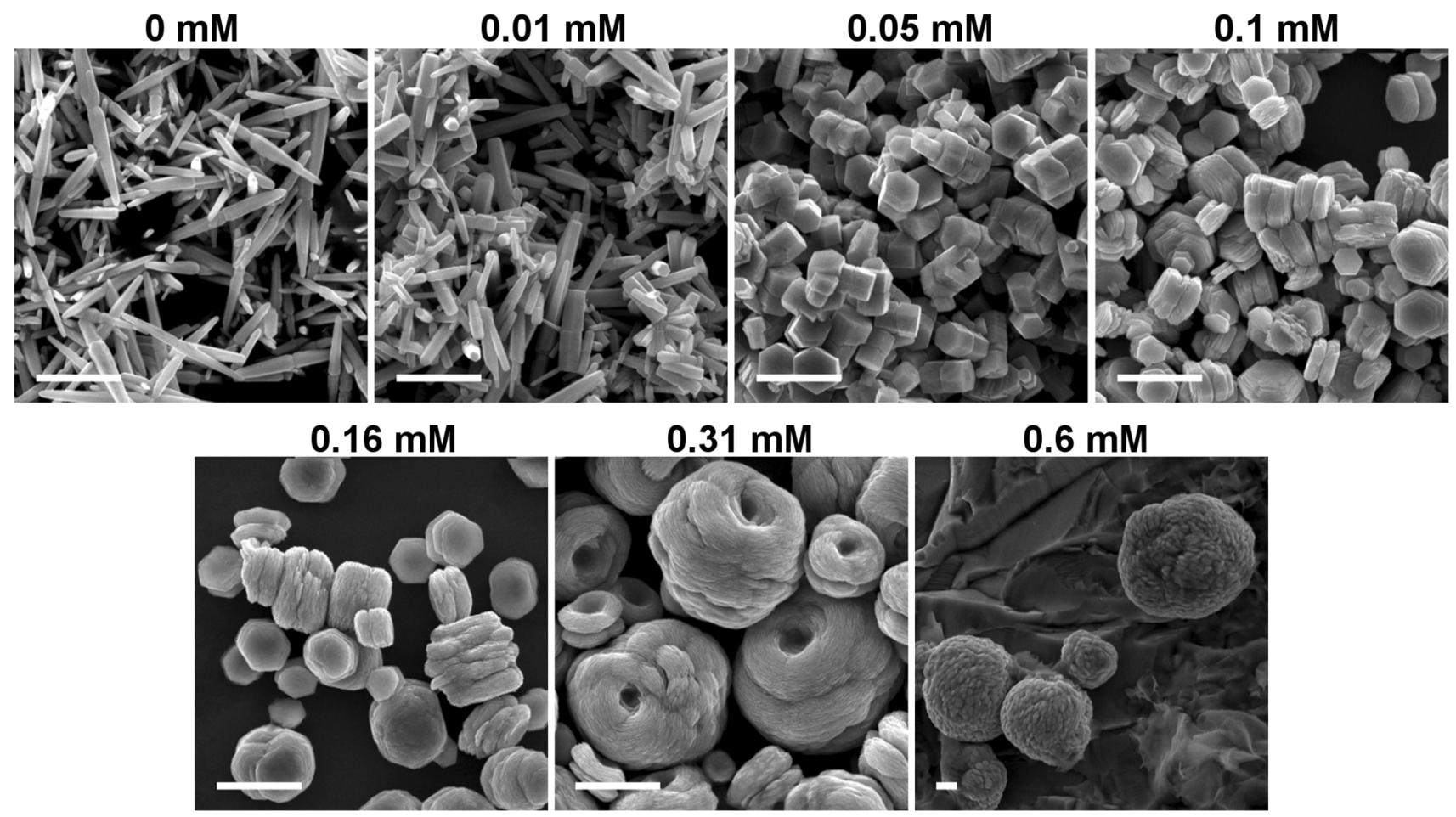

Fig. 4 Scanning electron microscopy (SEM) images of $\mathrm{ZnO}$ nanostructures synthesized with the addition of varied peptide concentrations (scale bar $2 \mu \mathrm{m})$

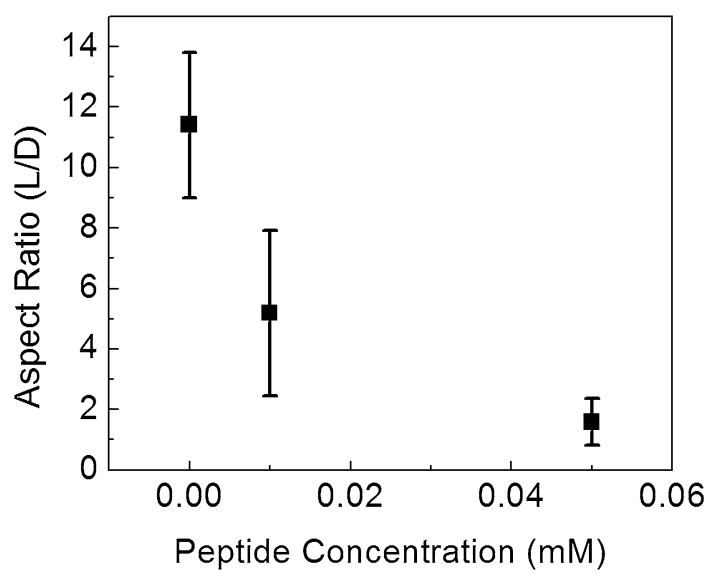

Fig. 5 Aspect ratio (length/diameter) of $\mathrm{ZnO}$ structures synthesized with the addition of peptide concentrations from 0 to $0.05 \mathrm{mM}$

reduced in samples synthesized with peptides and decreased with increasing peptide concentration, suggesting a reduction in oxygen and zinc vacancy-related defects within the $\mathrm{ZnO}$ material synthesized with peptide additives. At a peptide concentration of $0.05 \mathrm{mM}$, an increase in emission at wavelengths slightly longer than the band-edge peak was also observed. At peptide concentrations more than $0.31 \mathrm{mM}$, this $400 \mathrm{~nm}$ peak increased substantially, obscuring the band-edge emission. This sub-bandgap emission likely represented shallow donor to valence band

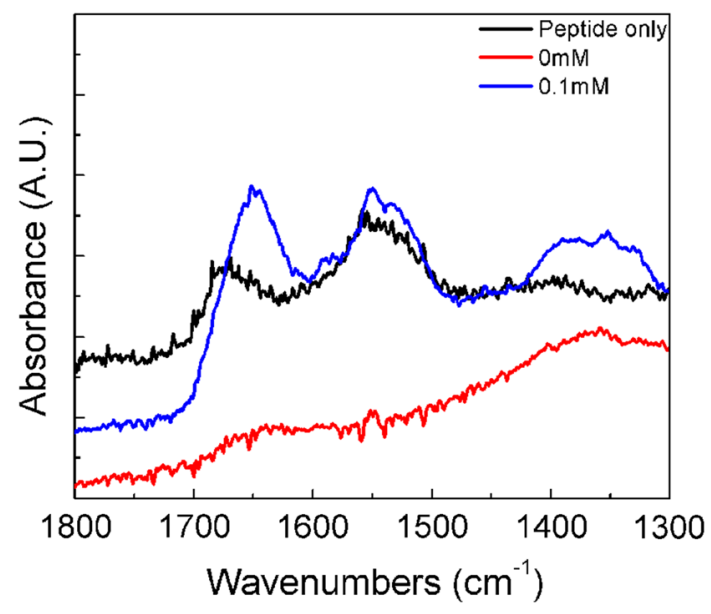

Fig. 6 Fourier transform infrared (FTIR) spectra of ZnO-binding peptide (black) and $\mathrm{ZnO}$ nanostructures prepared with no peptide (red) and $0.1 \mathrm{mM}$ peptide (blue). The absorbance of the $\mathrm{ZnO}$-binding peptide spectrum was multiplied by 3 to aid in visualization

and/or shallow acceptor to conduction band transitions of $\mathrm{Zn}_{\mathrm{i}}$ and $\mathrm{O}_{\mathrm{i}}$ interstitials, respectively [30]. Similar dominance of visible emission was observed from $\mathrm{ZnO}$ nanoparticles formed in the presence of spider silk peptides, as well as through some nonbiological processes [25, 31]. Peptide-assisted $\mathrm{ZnO}$ synthesis using the identified ZnO-binding peptide (VPGAAEHT) allowed hierarchical 


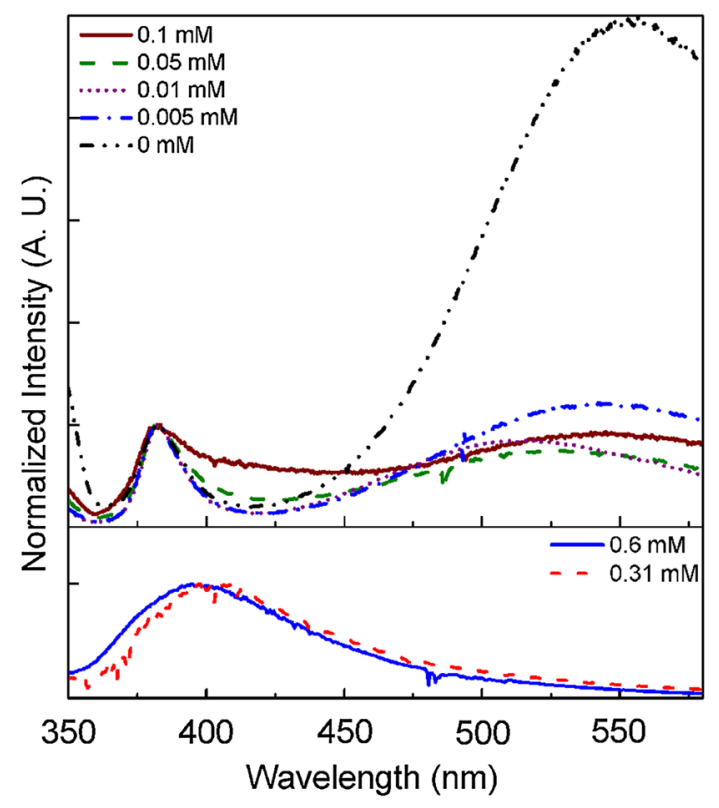

Fig. 7 Photoluminescence (PL) spectra of $\mathrm{ZnO}$ nanostructures formed with different peptide concentrations: top 0, 0.005, 0.01, $0.05,0.1$, and bottom $0.31,0.6 \mathrm{mM}$. Emission intensity was normalized to the band-edge or near band-edge peak

assembly of nanoscale $\mathrm{ZnO}$ that showed distinct, morphology-dependent optical emission properties.

\section{Conclusion}

In summary, a combinatorial pVIII phage display library, in which display of neutral and acidic peptides was favored, was used to find a peptide with an affinity for $\mathrm{ZnO}$. When added during synthesis, this $\mathrm{ZnO}$-binding peptide exhibited control over $\mathrm{ZnO}$ nanostructure crystallinity, morphology, and photoluminescence behavior. Higher peptide concentrations triggered an evolution from single crystal to polycrystalline particles, and a range of concentration-dependent $\mathrm{ZnO}$ nanostructures including rods, platelets, yarn-like shapes, and microspheres was observed. Photoluminescence spectra of materials synthesized with the $\mathrm{ZnO}$-binding peptide showed decreased green emission from surface-related oxygen and zinc vacancies as compared to materials synthesized without peptides. And, at greatly increased peptide concentrations, blue emission from interstitial defects acting as shallow donors and acceptors increased. Although further studies are necessary to elucidate specific mechanisms which enable adjustment of morphology and sub-bandgap emission, this study demonstrates the potential control of these properties offered by peptide-mediated growth. Engineered morphology and defect levels are valuable for $\mathrm{ZnO}$ gas sensing and photocatalytic materials design.
Acknowledgments The authors thank EL Hu (Harvard) and AM Belcher (MIT) for the gift of the M13SK vector and M Isarraraz (UCR) for early biopanning contributions. This work was supported in part by the Office of Naval Research (ONR, N00014-14-1-0799) and made use of the Central Facility for Advanced Microscopy and Microanalysis (CFAMM), Analytical Chemistry Instrumentation Facility (ACIF, NSF CHE-9974924 and AFOSR F49620-98-1-0475) and the Genomics Core at the Institute for Integrative Genome Biology (IIGB) at UCR. Peptide model was created with the UCSF Chimera package which was developed by Resource for Biocomputing, Visualization, and Informatics at the University of California, San Francisco (supported by NIGMS P41-GM103311).

\section{References}

1. A. Kolodziejczak-Radzimska, T. Jesionowski, Materials 7, 2833-2881 (2014)

2. M.W. Ahn, K.S. Park, J.H. Heo, J.G. Park, D.W. Kim, K.J. Choi, J.H. Lee, S.H. Hong, Appl. Phys. Lett. 93, 263103 (2008)

3. P.S. Venkatesh, P. Dharmaraj, V. Purushothaman, V. Ramakrishnan, K. Jeganathan, Sens. Actuators B Chem. 212, 10-17 (2015)

4. Z. Pei, L. Ding, J. Hu, S. Weng, Z. Zheng, M. Huang, P. Liu, Appl. Catal. B Environ. 142, 736-743 (2013)

5. S.G. Kumar, K.S.R.K. Rao, RSC Adv. 5, 3306-3351 (2015)

6. Y.C. Liao, C.S. Xie, Y. Liu, Q.W. Huang, J. Alloys Compd. 550, 190-197 (2013)

7. H. Bai, F. Xu, L. Anjia, H. Matsui, Soft Matter 5, 966-969 (2009)

8. Y. Wang, X. Liao, Z. Huang, G. Yin, J. Gu, Y. Yao, Colloid Surf. A 372, 165-171 (2010)

9. M. Umetsu, M. Mizuta, K. Tsumoto, S. Ohara, S. Takami, H. Watanabe, I. Kumagai, T. Adschiri, Adv. Mater. 17, 2571-2575 (2005)

10. Z. Wei, Y. Maeda, H. Matsui, Angew. Chem. Int. Ed. 50, 10585-10588 (2011)

11. M.M. Tomczak, M.K. Gupta, L.F. Drummy, S.M. Rozenzhak, R.R. Nalk, Acta Biomater. 5, 876-882 (2009)

12. L. Anjia, Z. Wei, H. Matsui, RSC Adv. 2, 5516-5519 (2012)

13. P. Gerstel, R.C. Hoffmann, P. Lipowsky, L.P.H. Jeurgens, J. Bill, F. Aldinger, Chem. Mater. 18, 179-186 (2006)

14. C.K. Thai, H.X. Dai, M.S.R. Sastry, M. Sarikaya, D.T. Schwartz, F. Baneyx, Biotechnol. Bioeng. 87, 129-137 (2004)

15. D. Rothenstein, B. Claasen, B. Omiecienski, P. Lammel, J. Bill, J. Am. Chem. Soc. 134, 12547-12556 (2012)

16. P. Golec, J. Karczewska-Golec, M. Los, G. Wegrzyn, J. Nanopart. Res. 14, 1218 (2012)

17. M.-K. Liang, O. Deschaume, S.V. Patwardhan, C.C. Perry, J. Mater. Chem. 21, 80-89 (2011)

18. S.R. Whaley, D.S. English, E.L. Hu, P.F. Barbara, A.M. Belcher, Nature 405, 665-668 (2000)

19. S.K. Lee, D.S. Yun, A.M. Belcher, Biomacromolecules 7, 14-17 (2006)

20. S. Donatan, H. Yazici, H. Bermek, M. Sarikaya, C. Tamerler, M. Urgen, Mater. Sci. Eng. C Biomim. 29, 14-19 (2009)

21. E.F. Pettersen, T.D. Goddard, C.C. Huang, G.S. Couch, D.M. Greenblatt, E.C. Meng, T.E. Ferrin, J. Comput. Chem. 25, 1605-1612 (2004)

22. H. Sawada, R.P. Wang, A.W. Sleight, J. Solid State Chem. 122, 148-150 (1996)

23. T. Togashi, N. Yokoo, M. Umetsu, S. Ohara, T. Naka, S. Takami, H. Abe, I. Kumagai, T. Adschiri, J. Biosci. Bioeng. 111, 140-145 (2011)

24. J. Baier, N.J. Blumenstein, J. Preusker, L.P.H. Jeurgens, U. Welzel, T.A. Do, J. Pleiss, J. Bill CrystEngComm 16, 5301-5307 (2014) 
25. Z. Huang, D. Yan, M. Yang, X. Liao, Y. Kang, G. Yin, Y. Yao, B. Hao, J. Colloid Interface Sci. 325, 356-362 (2008)

26. M.J. Limo, R. Ramasamy, C.C. Perry, Chem. Mater. 27, 1950-1960 (2015)

27. S.H. Kim, T.Y. Olson, J.H. Satcher Jr, T.Y.-J. Han, Microporous Mesoporous Mater. 151, 64-69 (2012)

28. A. Barth, Prog. Biophys. Mol. Biol. 74, 141-173 (2000)
29. S. Dutta, S. Chattopadhyay, A. Sarkar, M. Chakrabarti, D. Sanyal, D. Jana, Prog. Mater. Sci. 54, 89-136 (2009)

30. P.S. Xu, Y.M. Sun, C.S. Shi, F.Q. Xu, J.B. Pan, Nucl. Instrum. Methods B 199, 286-290 (2003)

31. H. Zeng, G. Duan, Y. Li, S. Yang, X. Xu, W. Cai, Adv. Funct. Mater. 20, 561-572 (2010) 